\title{
Analisis dan Perancangan Simulasi Jaringan MAN (Metropolitan Area Network) dengan Dynamic Routing EIGRP (Enhanced Interior Gateway Routing Protocol) dan Algoritma DUAL (Diffusing Update Algorithm) Menggunakan Cisco Packet Tracer
}

\author{
Nofita Rismawati ${ }^{1}$, Muhamad Femy Mulya ${ }^{2}$ \\ ${ }^{1}$ Program Studi Teknik Informatika, Universitas Indraprasta PGRI, Jakarta, Indonesia \\ ${ }^{2}$ Program Studi Sistem Informasi, Tanri Abeng University, Jakarta, Indonesia \\ ${ }^{1}$ novi.9001@gmail.com, ${ }^{2}$ femy.mulya@tau.ac.id
}

Diterima 07 Maret 2020

Disetujui 30 maret 2020

\begin{abstract}
Jaringan komputer perlu dikelola dengan benar sehingga lalu lintas data di jaringan menjadi lebih efisien. Satu tingkat manajemen jaringan komputer adalah perangkat router. Router dapat dikelola dengan mengimplementasikan protokol routing, salah satunya adalah EIGRP (Enhanced Interior Gateway Routing Protocol). EIGRP adalah protokol perutean yang hanya diadopsi oleh router Cisco atau sering disebut sebagai protokol milik Cisco, di mana EIGRP hanya dapat digunakan pada router Cisco saja. EIGRP sangat cocok untuk perusahaan menengah dan besar, karena banyaknya fasilitas yang disediakan dalam protokol ini. Tujuan dari penelitian ini adalah untuk menganalisis, merancang topologi MAN (Metropolitan Area Network) dengan routing dinamis EIGRP (Enhanced Interior Gateway Routing Protocol) dan algoritma DUAL (Diffusing Update Algorithm), sehingga jalur routing terbaik untuk topologi MAN akan diperoleh, sehingga topologi MAN akan dirancang. Perangkat lunak yang digunakan untuk membuat EIGRP (Enhanced Interior Gateway Routing Protocol) dan DUAL (Algoritma Pembaruan Pembaruan) simulasi menggunakan Cisco Packet Tracer. Dari hasil pengujian simulasi membuktikan bahwa jalur terbaik untuk dilalui oleh setiap router, yaitu jalur / rute yang memiliki perhitungan metrik EIGRP terkecil di antara rute tetangga, perhitungan ini diperoleh dari parameter bandwidth dan delay pada setiap router yang terhubung.
\end{abstract}

Keyword - EIGRP (Enhanced Interior Gateway Routing Protocol), DUAL (Diffusing Update Algorithm), Metric EIGRP

\section{PENDAHULUAN}

Seiring perkembangan teknologi komunikasi jaringan saat ini, komputer sudah menjadi alat bantu yang tidak bisa dilepaskan dari kehidupan kita sehari-hari. Mulai dari sekedar mengerjakan tugas, sampai dengan kebutuhan bersosialisasi melalui website (situs) jejaring sosial. Komputer yang dahulunya tidak bisa terhubung dengan komputer lainnya atau hanya berdiri sendiri, sekarang menjadi sebuah keharusan untuk terhubung dengan komputer lainnya, baik melalui jaringan lokal (intranet), atau melalui jaringan internet melalui koneksi jaringan seluler yang semakin hari, harganya semakin terjangkau oleh semua orang.

Jaringan komputer merupakan sekumpulan komputer berjumlah banyak yang terpisah-pisah akan tetapi saling berhubungan dalam melaksanakan tugasnya. Dua buah komputer misalnya dikatakan terkoneksi bila keduanya dapat saling bertukar informasi. Bentuk koneksi dapat melalui: kawat tembaga, serat optik, gelombang mikro dan satelit komunikasi. Dengan adanya jaringan komputer, maka informasi yang dipertukarkan antara beberapa komputer menjadi lebih mudah dan cepat.

MAN (Metropolitan Area Network) adalah suatu jaringan dalam suatu kota dengan transfer data berkecepatan tinggi, yang menghubungkan berbagai lokasi seperti kampus, perkantoran, pemerintahan, dan sebagainya. Jaringan MAN juga dapat disebut sebagai gabungan dari beberapa LAN.

EIGRP (Enhanced Interior Gateway Routing Protocol) adalah routing protocol yang hanya di adopsi oleh router cisco atau sering disebut sebagai proprietary protocol pada cisco. Dimana EIGRP hanya bisa digunakan sesama router cisco. EIGRP berfungsi untuk menghubungkan router 
satu dengan router yang lain dengan cara mengenalkan network-network pada setiap interface yang berada pada router itu sendiri, merupakan hasil pengembangan dari routing protocol pendahulunya yaitu IGRP yang keduanya adalah routing pengembangan dari CISCO.

EIGRP menggabungkan kemampuan dari Link-State Protocol dan Distance Vector Protocol, terlebih lagi EIGRP memuat beberapa protocol penting yang secara baik meningkatkan efisiensi penggunaannya ke routing protocol lain[1].

Dari uraian yang telah diberikan, Pada penelitian ini akan dirancang sebuah simulasi jaringan MAN (Metropolitan Area Network) dengan routing dinamik EIGRP (Enhanced Interior Gateway Routing Protocol) untuk menentukan jalur terbaik routing dengan Algoritma DUAL (Diffusing Update Algorithm). Implementasi EIGRP (Enhanced Interior Gateway Routing Protocol) pada hasil rancangan arsitektur MAN dapat dilakukan dengan cara memberikan konfigurasi pada router di dalam rancangan arsitektur dan menguji coba hasil konfigurasi untuk mengetahui informasi terkait EIGRP. Simulasi paket data pada hasil rancangan MAN dan EIGRP dilakukan dengan cara ujicoba untuk menemukan successor dan feasible successor, dimana Sebuah feasible successor merupakan router tetangga yang memiliki jalur cadangan yang layak untuk jaringan yang sama dengan successor. Untuk menjadi feasible successor, R1 harus memiliki kondisi kelayakannya. Feasibility Condition (FC) terpenuhi jika Reported Distance (RD) suatu jaringan dari tetangga ternyata kurang dari Feasible Distance sebuah router dengan jarak jaringan yang sama.

Tujuan dari penelitian ini adalah untuk menganalisa, merancang suatu topologi jaringan MAN (Metropolitan Area Network) dengan routing dinamik EIGRP (Enhanced Interior Gateway Routing Protocol) dan Algoritma DUAL (Diffusing Update Algorithm), sehingga akan diperoleh jalur terbaik routing untuk topologi MAN yang akan dirancang. Perangkat lunak yang digunakan untuk membuat simulasi EIGRP (Enhanced Interior Gateway Routing Protocol) dan Algoritma DUAL (Diffusing Update Algorithm) ini Menggunakan Cisco Packet Tracer.

\section{LANDASAN TEORI}

\section{A. Router}

Router adalah suatu alat jaringan komputer yang digunakan untuk mengirimkan paket data dari suatu jaringan menuju tujuannya melalui proses yang dikenal sebagai routing. Proses routing terjadi di layer 3 dari tujuh lapisan osi layer. Router adalah komputer yang memiliki komponen dasar yang sama seperti komputer PC biasa, tetapi router di desain untuk melakukan fungsi tertentu. Misalkan untuk menghubungkan dan menyediakan proses komunikasi diantara dua jaringan dan menentukan jalur terbaik untuk perjalanan data melalui jaringan yang terhubung. Router menggunakan protokol routing untuk menentukan jalur terbaik untuk setiap paket data yang akan dikirimkannya.

\section{B. Routing}

Routing adalah proses pemilihan jalur di jaringan yang digunakan untuk mengirimkan paket data ke alamat tujuan. Router membuat keputusan routing berdasarkan IP address tujuan dari paket. Istilah routing digunakan untuk pemilihan jalur sebuah paket dari sebuah jaringan ke jaringan lain yang saling terhubung melalui router. Pada suatu sistem jaringan komputer, router menyimpan informasi tentang routing didalam tabel routing. Router akan berpedoman pada tabel routing ini untuk menentukan jalur mana yang digunakan untuk mencapai network tujuan terhadap paket-paket yang dilewatkan kepadanya[2].

\section{EIGRP (Enhanced Interior Gateway Routing Protocol)}

EIGRP (Enhanced Interior Gateway Routing Protocol) adalah routing protocol yang hanya di adopsi oleh router Cisco atau sering disebut sebagai proprietary protocol pada Cisco. Dimana EIGRP ini hanya bisa digunakan sesama router Cisco saja dan routing ini tidak didukung dalam jenis router yang lain[3].

EIGRP sering disebut juga hybrid-distancevector routing protocol, karena cara kerjanya menggunakan dua tipe routing protocol, yaitu Distance vector protocol dan Link-State protocol, Dalam pengertian bahwa routing EIGRP sebenarnya merupakan distance vector protocol tetapi prinsip kerjanya menggunakan links-states protocol. Sehingga EIGRP disebut sebagai hybrid-distance-vector, mengapa dikatakan demikian karena prinsip kerjanya sama dengan links-states protocol yaitu mengirimkan semacam 
hello packet. EIGRP menggunakan formula berbasis bandwidth dan delay untuk menghitung metric yang sesuai dengan suatu rute. EIGRP melakukan konvergensi secara tepat ketika menghindari loop.[4]

\section{Tipe Packet pada EIGRP}

EIGRP memiliki beberapa tipe paket yaitu sebagai berikut[5]:

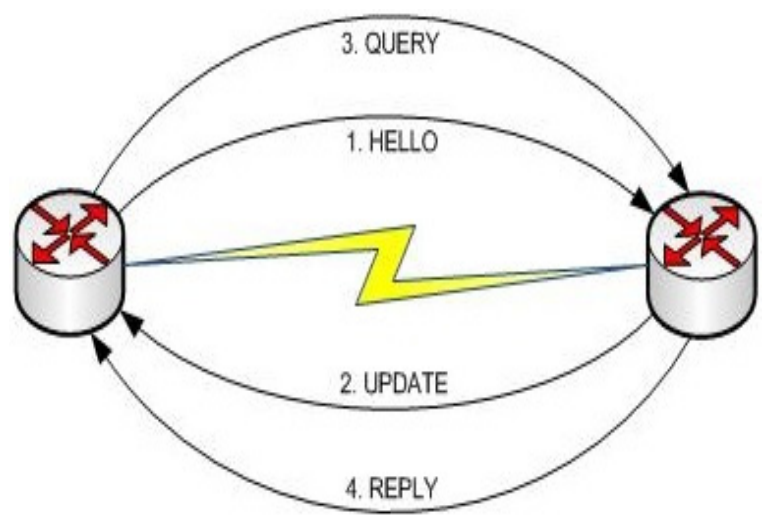

Gambar 1. Tipe packet pada EIGRP[5]

1. Hello: Paket hello digunakan untuk mengidentifikasi keberadaan dirinya kepada router tetangga, untuk membentuk neighborship.

2. Update: EIGRP akan mengirimkan packet update jika memang ada update/perubahan konfigurasi.

3. Query: Digunakan untuk menanyakan rute terbaik sebelumnya yang telah hilang. Jika update menemukan adanya path yang hilang maka multicast queries akan dikirim untuk menanyakan router tetangga apakah masih memiliki path tersebut. Apabila tidak mendapat respon, maka router yang kehilangan path akan mencoba mengirimkan paket unicast query, satu-per satu ke setiap router tetangga hingga 16 kali pengulangan.

4. Reply: Digunakan untuk menjawab query. Setiap router yang menerima query akan merespon dengan mengirim paket reply secara unicast.

\section{E. Tabel EIGRP}

EIGRP mempunyai 3 buah table routing sebagai berikut[4]:

1. Tabel Neighbor: Berisi list router-router terhubung langsung yang menjalankan proses EIGRP dan ber-adjacency dengan router ini. Ketika sebuah router menemukan neighbor baru maka router akan menyimpan alamat neighbor dan interface-nya.

2. Tabel Topology: Berisi semua informasi routing (routes) yang didapatkan dari setiap neighbor EIGRP. Di dalamnya terdapat semua successor, feasible successor (FS), feasible Distance (FD), Advertised distance (AD) dan Outgoing interface.

$\checkmark$ Feasible successor (FS) digunakan untuk semua neighbor atau router tetangga yang memenuhi kondisi feasibility requirement.

$\checkmark$ Feasible Distance (FD) merupakan metric dari router asal ke router tujuan.

$\checkmark$ Advertise Distance (AD) merupakan metric dari neighbor atau router tetangga hingga sampai mencapai tujuan.

$\checkmark$ DUAL (Diffusing Update Algorithm) beraksi pada topology table untuk menentukan successors dan (FS) feasible successors yang akan digunakan untuk pembentukan routing table.

3. Tabel Routing: Berisi semua jalur terbaik (best routes) dari list routes dalam tabel topologi EIGRP. Kadang disebut sebagai tabel successor Routing table terbentuk setelah tabel topology terbentuk.

\section{F. Metric EIGRP}

EIGRP melakukan perhitungan dengan menggunakan parameter $\mathbf{K}$ value, berikut beberapa parameter metric pada perhitungan EIGRP[6]:

Default Composite Formula:

Metric $=[\mathrm{K} 1 *$ Bandwidth $+\mathrm{K} 3 *$ Delay $] * 256$

\section{Complete Composite Formula (not used if " $K$ " Values are "0"): \\ Metric $=[\mathrm{K} 1 *$ Bandwidth + \\ $(\mathrm{K} 2 *$ Bandwidth $) /(256-$ load $)+\mathrm{K} 3 *$ Delay $] *$ \\ [K5/(Reliability + K4)]}

\section{Syntax Router Configuration Command:}

Router (config-router)\# metric weights tos $k 1 k 2 k 3 k 4 k 5$

Contoh Perhitungan Metric:

a. Bandwidth: EIGRP Router akan memilih diantara interface-interface yang mana paling lambat untuk dijadikan barometer untuk kalkulasi metric. 


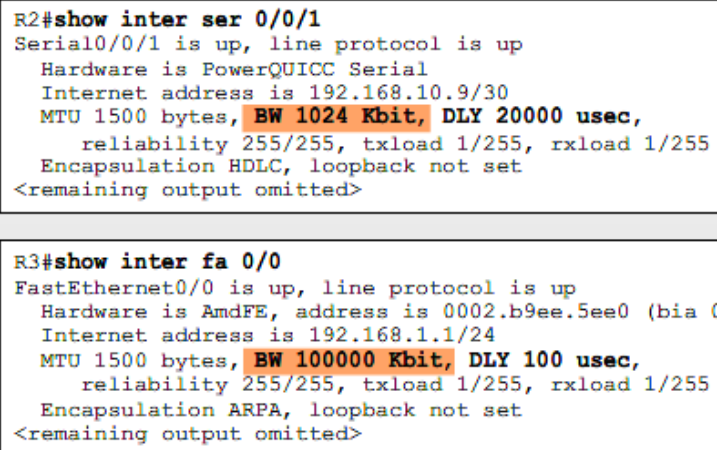

bandwidth $=(10,000,000 / 1024)=9765 * 256=2499840$

Gambar 2. Contoh Perhitungan Metric Bandwidth

b. Delay: Menggunakan jumlah kumulatif dari metric delay interface.

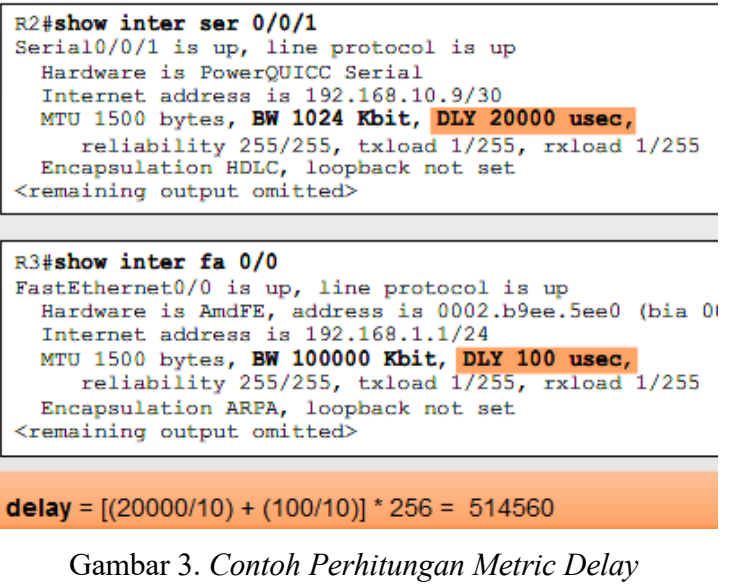

Gambar 3. Contoh Perhitungan Metric Delay

c. Hasil Metric EIGRP

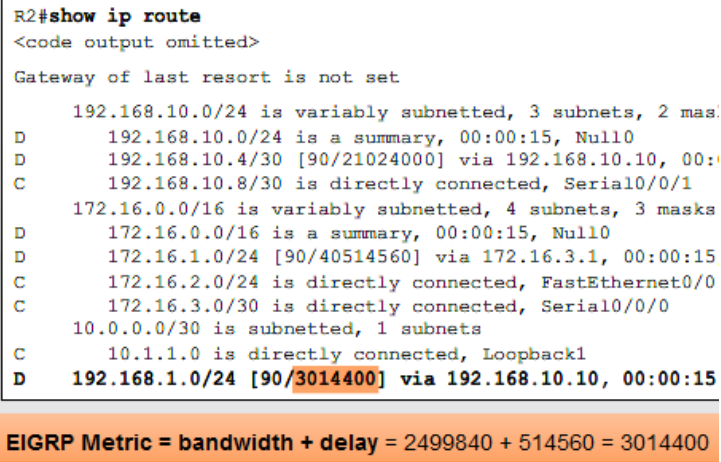

Gambar 4. Hasil Perhitungan Metric EIGRP

\section{G. Algoritma DUAL (Diffusing Update} Algorithm)

Algoritma DUAL digunakan untuk mengkalkulasikan dan membangun sebuah routing table dan untuk memastikan sebuah jalur untuk sebuah network dan menyediakan sebuah loopless routing environment agar membantu mengirimkan sebuah packet ke sebuah jaringan.
Routing loopless dapat terjadi ketika update informasi tentang hilangnya suatu rute, karena hal ini tidak dapat diterima oleh semua router pada network. Hal ini, bisa terjadi karena paket update mengalami kerusakan (corrupt) atau terbuang (dropped). Sehingga router-router yang menerima update akan beranggapan saat ini terjadi masalah pada network.

Bagaimana cara kerja Diffusing Update Algorithm untuk menetukan pilihan jalur terbaik pada protokol routing EIGRP menggunakan dua parameter acuan yaitu Bandwidth dan Delay. Kemudian di uji dengan menggunakan metode QoS. Quality of Service adalah kemampuan sebuah jaringan untuk menyediakan layanan yang lebih baik lagi bagi layanan trafik yang melewatinya[7].

\section{METODE PENELITIAN}

Untuk menganalisa dan merancang simulasi jaringan MAN (Metropolitan Area Network) dengan Dynamic Routing EIGRP (Enhanced Interior Gateway Routing Protocol) dan Algoritma DUAL (Diffusing Update Algorithm) Menggunakan Cisco Packet Tracer, maka pada penelitian ini akan menggunakan alur tahapan penelitian sebagai berikut:

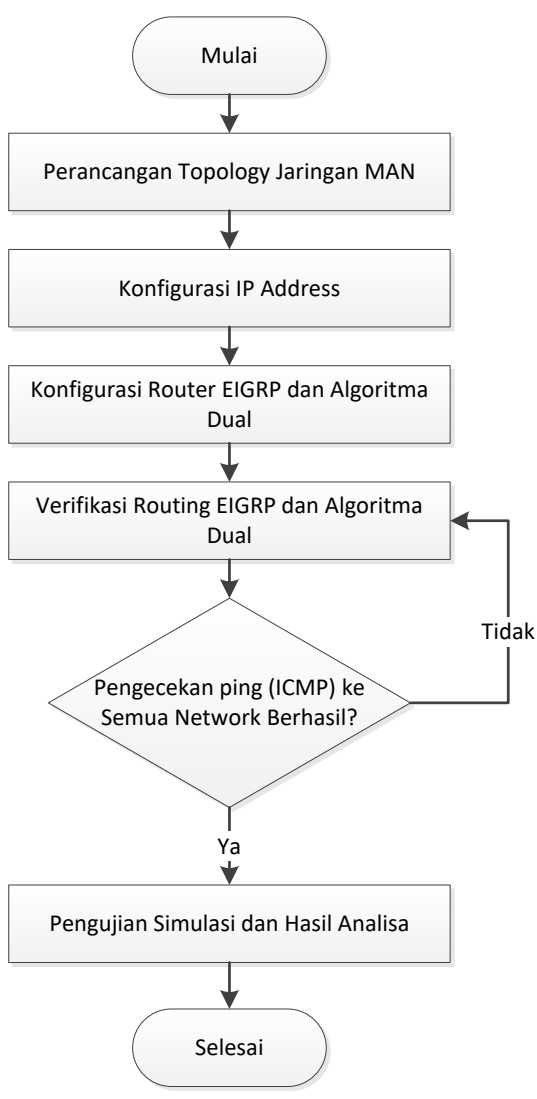

Gambar 5. Alur Tahapan Penelitian 


\section{Jurnal Sistem Komputer dan Kecerdasan Buatan}

Vol. III No. 2 Tahun 2020

\section{HASIL DAN PEMBAHASAN}

\section{A. Desain / Perancangan Topologi Jaringan MAN}

Pada perancangan topologi jaringan MAN akan menggunakan 3 buah Router yang masing- masing akan terhubung ke setiap segmen network yang berbeda lokasi (lokasi setiap segmen masuk ruang lingkup area MAN). Adapun Desain Topologi Jaringan MAN pada Cisco Packet Tracer sebagai berikut:

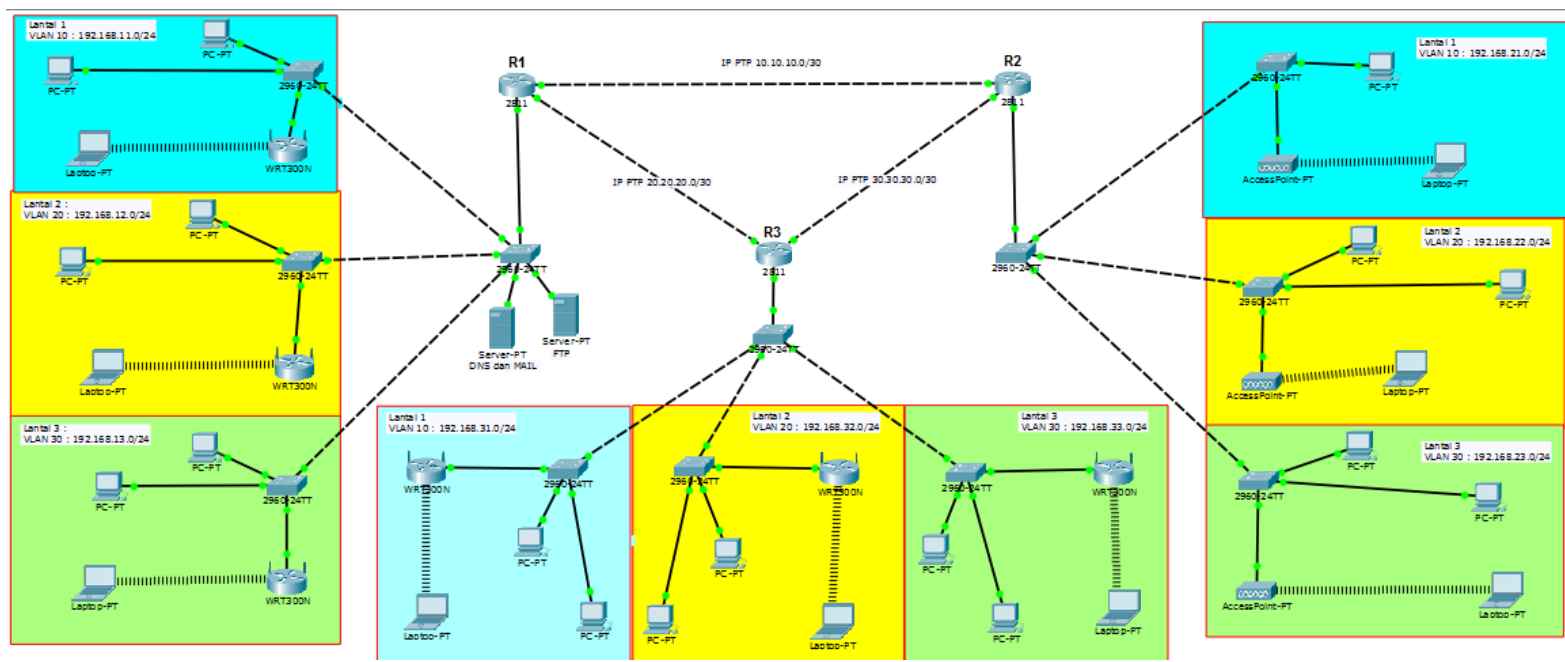

Gambar 6. Desain/Perancangan Topologi Jaringan MAN

\section{B. Konfigurasi IP Address}

Untuk membuat desain/perancangan topologi jaringan MAN dengan routing dinamik EIGRP dan Algoritma DUAL, maka perlu dilakukan alokasi pengalamatan IP yang sesuai dengan perhitungan subnetting, adapun tabel IP Address (Alokasi IP Address) untuk jaringan MAN-nya sebagai berikut:

Tabel 1. Konfigurasi IP Address

\begin{tabular}{|c|c|c|c|c|c|}
\hline Lokasi & Device & Interface & IP address & Subnetmask & IP Gateway \\
\hline \multirow{5}{*}{$\begin{array}{c}\text { Office 1 } \\
\text { (Segmen 1) }\end{array}$} & \multirow{5}{*}{ R1 } & $\mathrm{Fa} 0 / 1$ & 10.10 .10 .1 & 255.255 .255 .252 & \\
\hline & & $\mathrm{Fa} 1 / 0$ & 30.30 .30 .1 & 255.255 .255 .252 & \\
\hline & & $\mathrm{Fa} 0 / 0.1$ & 192.168.11.1 & 255.255 .255 .0 & \\
\hline & & $\mathrm{Fa} 0 / 0.2$ & 192.168.12.1 & 255.255 .255 .0 & \\
\hline & & $\mathrm{Fa} 0 / 0.3$ & 192.168.13.1 & 255.255 .255 .0 & \\
\hline lantai 1 & PC \& Laptop & NIC & $192.168 .11 .2-254$ & 255.255 .255 .0 & 192.168.11.1 \\
\hline lantai 2 & PC \& Laptop & NIC & $192.168 .12 .2-254$ & 255.255 .255 .0 & 192.168 .12 .1 \\
\hline \multirow[t]{3}{*}{ lantai 3} & PC \& Laptop & NIC & $192.168 .13 .2-254$ & 255.255 .255 .0 & 192.168 .13 .1 \\
\hline & $\begin{array}{c}\text { PC DNS \& } \\
\text { Mail }\end{array}$ & NIC & 192.168 .11 .250 & 255.255 .255 .0 & 192.168 .11 .1 \\
\hline & PC FTP & NIC & 192.168 .11 .250 & 255.255 .255 .0 & 192.168 .11 .1 \\
\hline \multirow{5}{*}{$\begin{array}{c}\text { Office 2 } \\
\text { (Segmen 2) }\end{array}$} & \multirow{5}{*}{$\mathrm{R} 2$} & $\mathrm{Fa} 0 / 1$ & 10.10 .10 .2 & 255.255 .255 .252 & \\
\hline & & $\mathrm{Fa} 1 / 0$ & 20.20 .20 .1 & 255.255 .255 .252 & \\
\hline & & $\mathrm{Fa} / 0.1$ & 192.168 .21 .1 & 255.255 .255 .0 & \\
\hline & & $\mathrm{Fa} 0 / 0.2$ & 192.168.22.1 & 255.255 .255 .0 & \\
\hline & & $\mathrm{Fa} 0 / 0.3$ & 192.168.23.1 & 255.255 .255 .0 & \\
\hline lantai 1 & PC \& Laptop & NIC & $192.168 .21 .2-254$ & 255.255 .255 .0 & 192.168.21.1 \\
\hline lantai 2 & PC \& Laptop & NIC & $192.168 .22 .2-254$ & 255.255 .255 .0 & 192.168 .22 .1 \\
\hline lantai 3 & PC \& Laptop & NIC & $192.168 .23 .2-254$ & 255.255 .255 .0 & 192.168.23.1 \\
\hline \multirow{3}{*}{$\begin{array}{c}\text { Office } 3 \\
\text { (Segmen 3) }\end{array}$} & \multirow{3}{*}{ R3 } & $\mathrm{Fa} 0 / 0$ & 20.20.20.2 & 255.255 .255 .252 & \\
\hline & & $\mathrm{Fa} 0 / 1$ & 30.30 .30 .2 & 255.255 .255 .252 & \\
\hline & & $\mathrm{Fa} 1 / 0.1$ & 192.168 .21 .1 & 255.255 .255 .0 & \\
\hline
\end{tabular}




\begin{tabular}{|l|c|c|c|c|c|}
\hline & & Fa1/0.2 & 192.168 .22 .1 & 255.255 .255 .0 & \\
\cline { 3 - 6 } & & Fa1/0.3 & 192.168 .23 .1 & 255.255 .255 .0 & \\
\hline lantai 1 & PC \& Laptop & NIC & $192.168 .31 .2-254$ & 255.255 .255 .0 & 192.168 .31 .1 \\
\hline lantai 2 & PC \& Laptop & NIC & $192.168 .32 .2-254$ & 255.255 .255 .0 & 192.168 .32 .1 \\
\hline lantai 3 & PC \& Laptop & NIC & $192.168 .33 .2-254$ & 255.255 .255 .0 & 192.168 .33 .1 \\
\hline
\end{tabular}

\section{Konfigurasi Router EIGRP dan Algoritma Dual}

Dalam konfigurasi routing EIGRP, EIGRP menggunakan Autonomuos System Number (ASN). ASN merupakan Identifier yang digunakan untuk mengenali router EIGRP lainnya. Router eigrp hanya dapat berkomunikasi dengan router EIGRP lain yang berada dalam satu ASN yang sama.

Syntax Konfigurasi ASN pada router EIGRP: Router (config-router)\# router eigrp [ASN]

\section{Syntax Konfigurasi ASN pada router EIGRP:} Router (config-router)\# network [network address] [wildcard mask]

Network address pada perintah di atas adalah untuk meng-advertise network yang terhubung secara langsung dengan router. EIGRP menggunakan wildcard mask, kebalikan dari subnet mask tapi fungsinya sama untuk menentukan subnet. Adapun konfigurasi untuk ketiga router dari topologi MAN yang sudah di rancang.

Rl
\begin{tabular}{|l|l|}
\hline R1(config)\#router eigrp 10 \\
R1(config-router)\#network 10.10.10.0 0.0.0.5 \\
R1(config-router)\#network 20.20.20.0 00.0 .0 .5 \\
R1(config-router)\#network 192.168.11.0 0.0.0.255 \\
R1(config-router)\#network 192.168.12.0 0.0.0.255 \\
R1(config-router)\#network 192.168.13.0 0.0.0.255 \\
R1(config-router)\#no auto-summary \\
\hline
\end{tabular}

Gambar 7. Konfigurasi EIGRP \& DUAL untuk Router 1

R2

R2(config)\#router eigrp 10
R2(config-router)\#network 10.10.10.0 0.0.0.5
R2(config-router)\#network 30.30.30.0 0 0.0.0.5
R2(config-router)\#network 192.168.21.0 0.0 .0 .255
R2(config-router)\#network 192.168.22.0 0.0 .0 .255
R2(config-router)\#network 192.168.23.0 0.0 .0 .255
R2(config-router)\#no auto-summary

Gambar 8. Konfigurasi EIGRP \& DUAL untuk Router 2
R3

R3(config)\#router eigrp 10

R3(config-router)\#network 20.20.20.0 0.0.0.5

R3(config-router)\#network 30.30.30.0 0 0.0.0.5

R3(config-router)\#network 192.168.31.0 0.0.0.255

R3(config-router)\#network 192.168.32.0 0.0.0.255

R3(config-router)\#network 192.168.33.0 0.0.0.255

R3(config-router)\#no auto-summary

Gambar 9. Konfigurasi EIGRP \& DUAL untuk Router 3

Perintah no auto-summary digunakan agar network address tidak disummarisasi (auto summarize). Untuk beberapa kasus, perintah ini sangat penting karena jika tidak menggunakan perintah ini, bisa-bisa routing akan menjadi kacau.

\section{Verifikasi Routing EIGRP dan Algoritma $D U A L$}

Setelah dilakukan Konfigurasi EIGRP dan algoritma DUAL pada Router 1, 2 dan 3, maka tahapan selanjutnya akan dilakukan verifikasi routing dengan melakukan pengecekan terhadap IP EIGRP Neighbor dan table topology EIGRP.

R1

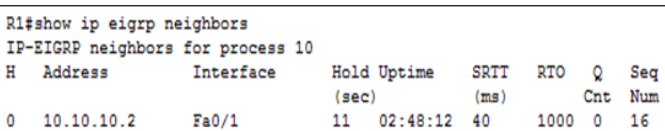

Gambar 10. IP EIGRP Neighbor Router 1

R2

\begin{tabular}{|c|c|c|c|c|c|c|c|c|}
\hline \multicolumn{9}{|c|}{ for process 10} \\
\hline & & & ise & & (ms) & & $\mathrm{Cnt}$ & Nur \\
\hline 0 & $10.10 \cdot 10.1$ & Fao/1 & 13 & $02: 48: 30$ & 40 & 1000 & 0 & 17 \\
\hline & 30.30 .30 .2 & $\mathrm{Fa} 1 / 0$ & 14 & $02: 48: 30$ & 40 & 1000 & 0 & 15 \\
\hline
\end{tabular}

Gambar 11. IP EIGRP Neighbor Router 2

R3

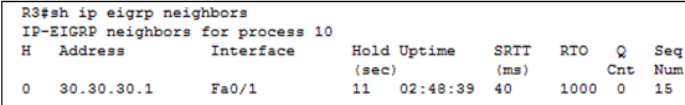

Gambar 12. IP EIGRP Neighbor Router 3

Dari Gambar 10, $11 \& 12$ terlihat bahwa $I P$ EIGRP Neighbor sudah sesuai dengan aturan pada routing dinamik EIGRP dan algoritma DUAL. Adapun penjelasan untuk masing-masing parameter pada IP EIGRP Neighbor untuk setiap router-nya sebagai berikut: 


\section{Jurnal Sistem Komputer dan Kecerdasan Buatan}

Vol. III No. 2 Tahun 2020

1. H (Handle) merupakan sebuah angka yang digunakan oleh IOS untuk melacak sebuah neighbor.

2. Address merupakan alamat network-layer dari neighbor.

3. Interface merupakan interface router yang terhubung dengan neighbor.

4. Hold Time merupakan waktu maksimum dalam detik, jika router tidak mendapatkan paket apapun dari neighbor dalam waktu tersebut maka neighbor akan dianggap tidak available lagi. Pada mulanya, paket yang ditunggu oleh router adalah Hello Packet, tetapi pada IOS software yang baru, setiap paket dari neighbor yang diterima setelah Hello Packet pertama dapat me-reset timer ini.

5. Uptime merupakan Waktu dalam hitungan jam, menit, dan detik sejak router lokal pertama kali dikenali dari neighbor ini.

6. SRTT (Smooth Round Trip Timer) merupakan jumlah rata-rata dalam milidetik yang dibutuhkan agar sebuah paket dikirimkan pada neighbor dan agar router lokal menerima acknowledgment dari paket tersebut. Timer ini digunakan sebagai interval untuk melakukan transmisi ulang, juga disebut retransmission timeout (RTO).

7. RTO (Restransmit Time Out) merupakan jumlah waktu dalam milidetik dimana router akan menunggu sebuah acknowledgment sebelum mengirim ulang paket kepada neighbor.

8. Q Cnt (Queue Count) merupakan jumlah EIGRP packet (update, query, dan replay) yang menunggu dalam antrian, jika angka dari Q Cnt lebih besar dari “0” maka kemungkinan akan terjadi congestion (kepadatan traffic). Jika nilai "0" berarti tidak ada paket EIGRP dalam antrian.

9. Seq Num (Sequence Number) merupakan nomor urut dari update terakhir, query, atau paket replay yang diterima dari neighbor.
Kemudian setelah dilakukan pengecekan terhadap IP EIGRP Neighbor, maka tahap selanjutnya dilakukan pengecekan terhadap table topology EIGRP pada router 1 (informasi table topology EIGRP bisa diakses juga melalui router 2 dan 3, dengan informasi yang sama seperti router 1$)$.

\section{R1}

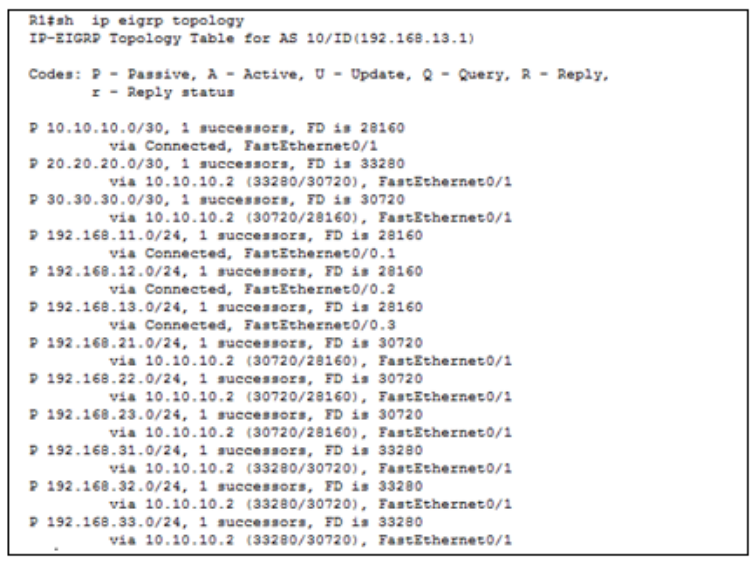

Gambar 13. Table Topology EIGRP Router 1

Pada Gambar 13 terlihat table topology yang menginfomasikan beberapa parameter seperti: ASN yang digunakan dalam router EIGRP, feasible distance (FD), Successor, Route EIGRP ID.

\section{E. Pengujian Simulasi dan Hasil Analisa}

Pada proses pengujian akan dilakukan perhitungan metric EIGRP pada masing-masing router 1, 2 dan 3, sehingga akan didapat best path (jalur terbaik) dari setiap rute router yang terhubung satu sama lainnya. Adapun hasil pengukuran parameter pada setiap rute sebagai berikut:

Tabel 2. Hasil Pengukuran Parameter Pada Setiap Rute

\begin{tabular}{|c|c|c|c|c|c|}
\hline \multirow{2}{*}{ Interface/Router } & Port & IP Network Tujuan & Bandwidth (Mbps) & Delay ( $\boldsymbol{\mu s )}$ & $\begin{array}{c}\text { Metric } \\
\text { EIGRP }\end{array}$ \\
\hline \multirow{2}{*}{$\mathrm{R} 1$} & $\mathrm{Fa} / 1 \mathrm{ke} \mathrm{R} 2$ & 10.10 .10 .1 & 500 & 100 & 10240 \\
\cline { 2 - 6 } & $\mathrm{Fa} 1 / 0 \mathrm{ke} \mathrm{R} 3$ & 30.30 .30 .1 & 100 & 100 & 30720 \\
\hline \multirow{2}{*}{$\mathrm{R} 2$} & $\mathrm{Fa} / 1 \mathrm{ke} \mathrm{R} 1$ & 10.10 .10 .2 & 100 & 100 & 30720 \\
\cline { 2 - 6 } & $\mathrm{Fa} 1 / 0 \mathrm{ke} \mathrm{R} 3$ & 20.20 .20 .1 & 500 & 100 & 10240 \\
\hline \multirow{2}{*}{$\mathrm{R} 3$} & $\mathrm{Fa} / 0 \mathrm{ke} \mathrm{R} 1$ & 20.20 .20 .2 & 500 & 100 & 10240 \\
\cline { 2 - 6 } & $\mathrm{Fa} / 1 \mathrm{ke} \mathrm{R} 2$ & 30.30 .30 .2 & 100 & 100 & 30720 \\
\hline
\end{tabular}


Berdasarkan hasil pengukuran parameter pada setiap rute yang terlihat pada tabel 1, maka jalur/rute best path (jalur terbaik) yang akan dilalui setiap router, yaitu jalur/rute yang memiliki perhitungan metric yang paling kecil diantara rute tetangga-nya. adapun dari hasil perhitungan dihasilkan rute sebagai berikut:

1. Router 1 akan menggunakan jalur/rute terbaik via Router 2.

2. Router 2 akan menggunakan jalur/rute terbaik via Router 3.

3. Router 3 akan menggunakan jalur/rute terbaik via Router 1 .

\section{KESIMPULAN DAN SARAN}

\section{A. Kesimpulan}

Berdasarkan penelitian dan hasil pengujian yang dilakukan terhadap simulasi jaringan MAN (Metropolitan Area Network) dengan dynamic routing EIGRP (Enhanced Interior Gateway Routing Protocol) dan algoritma DUAL (Diffusing Update Algorithm) Menggunakan Cisco Packet Tracer, maka didapatkan kesimpulan sebagai berikut:

1. Dari hasil pengukuran parameter dengan variabel perhitungan berupa bandwidth dan delay pada setiap jalur/rute yang terlihat pada table 1, maka untuk menentukan best path (jalur terbaik) pada routing EIGRP, dipilih jalur/rute yang memiliki perhitungan metric yang paling kecil diantara jalur/rute tetangganya.

2. Implementasi Enhanced Interior Gateway Routing Protocol (EIGRP) pada hasil rancangan arsitektur MAN dapat dilakukan dengan cara memberikan konfigurasi pada router di dalam rancangan arsitektur dan menguji coba hasil konfigurasi untuk mengetahui informasi terkait EIGRP.

3. EIGRP merupakan Satu-satunya protokol routing yang menggunakan route backup, selain me-maintain routing table terbaik, EIGRP juga menyimpan backup terbaik untuk setiap route sehingga setiap kali terjadi kegagalan pada jalur utama, maka EIGRP menawarkan jalur alternatif tanpa menunggu waktu convergence.

\section{B. Saran}

Berdasarkan hasil dari penelitian yang telah dilakukan oleh peneliti, berikut ini beberapa saran untuk pengembangan simulasi dynamic routing dengan perangkat lunak Cisco Packet Tracer, antara lain:

1. Perlu dilakukan analisa pembandingan dengan protokol lainnya, sehingga dapat menemukan suatu routing protocol yang lebih baik pada suatu rancangan arsitektur dan topologi jaringan komputer.

2. Perlu dilakukan penelitian lebih lanjut dengan menggunakan arsitektur dan topologi yang berbeda sehingga didapatkan nilai metric yang lebih baik pada jaringan yang terhubung router dengan konfigurasi EIGRP.

3. Perlu studi kasus nyata penerapan EIGRP sehingga dapat dinilai efektivitas dan efesiensi serta dampak dari konfigurasi router secara nyata tersebut, karena mungkin nilai hasil ujicoba simulasi berbeda dengan kenyataan di lapangan.

\section{DAFTAR PUSTAKA}

[1] N. Muhajir Abidin, D. M. Wiharta, and N. P. Sastra, "PERANCANGAN JARINGAN BACKBONE MENGGUNAKAN ROUTING PROTOCOL EIGRP DI FAKULTAS TEKNIK UNIVERSITAS UDAYANA KAMPUS JIMBARAN," $J$. SPEKTRUM, vol. 6, no. 1, p. 119, May 2019.

[2] S. A. Alabady, S. Hazim, and A. Amer, "Performance Evaluation and Comparison of Dynamic Routing Protocols for Suitability and Reliability," Int. J. Grid Distrib. Comput., vol. 11, no. 7, pp. 41-52, 2018.

[3] A. Aslin, K. Bai, M. X. M. Binisha, and P. G. Scholar, "Network Performance Analysis of Interior Gateway Routing Protocols using Gns3," 2018.

[4] A. ACHMAD, "IMPLEMENTASI ROUTING EIGRP PADA JARINGAN KOMPUTER," Fakt. Exacta, vol. 9, no. 4, pp. 324-332, Feb. 2017.

[5] "Basic Routing Protocol EIGRP Irwanalfiansyah's Blog." [Online]. Available: https://irwanalfiansyah.wordpress.com/2012/12/21/ ccie-bootcamp-idn-eigrp/. [Accessed: 07-Mar2020].

[6] E. Yusuf, D. Aryanta, and L. Lidyawati, "Perancangan dan Analisis Kinerja EIGRP pada Jaringan IPv6," 2016.

[7] T. D. Purwanto, "Analisis Kinerja Dynamic Routing pada Protokol Routing EIGRP untuk Menentukan Jalur Terbaik dengan Diffusing Update Algorithm (DUAL)," JUITA J. Inform., vol. 6, no. 2, p. 89, Nov. 2018. 
Jurnal Sistem Komputer dan Kecerdasan Buatan Vol. III No. 2 Tahun 2020 